\title{
Faktor-Faktor yang Berhubungan dengan Kadar Anti-Hhs pada Anak Sekolah Dasar Setelah 10-12 Tahun Imunisasi Hepatitis B Di Kota Padang
}

\author{
Lydia Aswati, Yusri Dianne Jurnalis, Yorva Sayoeti, Hafni Bachtiar
}

Bagian Ilmu Kesehatan Anak Fakultas Kedokteran Universitas Andalas, Padang

\begin{abstract}
Latar belakang. Hepatitis B merupakan masalah kesehatan global. Risiko kronis hepatitis B akan jauh lebih besar apabila infeksi terjadi pada awal kehidupan dibandingkan usia dewasa. Imunisasi merupakan cara efektif mengontrol infeksi hepatitis B sampai saat ini. Anak yang diimunisasi memperoleh proteksi selama 5-10 tahun. Kadar anti-HBs protektif adalah $\geq 10 \mathrm{mIU} / \mathrm{ml}$. Apabila daya proteksi setelah pemberian imunisasi pada masa bayi tidak dapat melindungi sampai dewasa, maka booster seharusnya diberikan pada umur prasekolah atau remaja.

Tujuan. Mengetahui faktor-faktor yang berhubungan dengan kadar anti-Hbs pada anak SD setelah 10 -12 tahun imunisasi hepatitis B

Metode. Penelitian cross sectional dari bulan Januari sampai Maret 2011 pada 110 anak SD di kota Padang yang berusia 10-12 tahun dan telah mendapatkan 3 kali imunisasi hepatitis B saat bayi. Analisis data menggunakan Chi-square dengan tingkat kemaknaan $\mathrm{p}=0,05$

Hasil. Dari 110 sampel didapatkan kadar anti-Hbs $<10 \mathrm{mIU} / \mathrm{ml}$ dan $\geq 10 \mathrm{mIU} / \mathrm{ml}$ masing-masing 58 $(52,7 \%)$ dan 52 (47,3\%) orang. Umur 12 tahun didapatkan kadar anti-Hbs $\geq 10 \mathrm{mIU} / \mathrm{ml}$ (35\%). Semua subyek mempunyai gizi baik. Tidak terdapat hubungan yang bermakna antara kadar anti-Hbs dengan jenis kelamin $(p=0,399)$ dan dengan jadwal imunisasi $(\mathrm{p}=0,364)$.

Kesimpulan. Subyek yang berumur lebih besar mempunyai kadar anti-HBs protektif lebih rendah. Tidak terdapat hubungan yang bermakna antara jenis kelamin, jadwal imunisasi dengan kadar anti_HBs setelah 10-12 tahun imunisasi Hepatitis B. Sari Pediatri 2013;14(5):303-8.
\end{abstract}

Kata kunci: hepatitis B, kadar anti-HBs, jenis kelamin, jadwal imunisasi

\footnotetext{
Alamat korespondensi:

Dr. Yusri Dianne Jurnalis, Sp.A. Divisi Gastrohepatologi Bagian Ilmu Kesehatan Anak Fakultas Kedokteran Unand. Telp. 081363931569/ Fax. (0751)37913. E-mail: yusridianne@yahoo.com
}

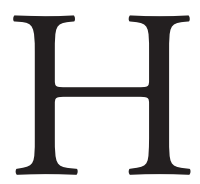

epatitis B merupakan masalah kesehatan global, diperkirakan sekitar dua miliar penduduk dunia pernah terkena virus hepatitis B (VHB). Virus hepatitis B telah menginfeksi lebih dari 350 juta orang di dunia atau kurang lebih 5\% populasi dunia. Infeksi VHB endemik di daerah Pasifik Barat dan Asia Tenggara, 
Lydia Aswati dkk: Faktor-faktor yang berhubungan dengan kadar anti-Hbs pada anak setelah 10-12 tahun imunisasi hepatitis B

diperkirakan 75\%-80\% dari infeksi VHB di dunia. ${ }^{1}$ Penularan umum terjadi secara vertikal (pada periode perinatal) dan horizontal (pada masa anak-anak). ${ }^{1-4}$

Imunisasi adalah cara efektif mengontrol infeksi VHB sampai saat ini. Prevalensi infeksi hepatitis B kronik, hepatitis B fulminan, dan karsinoma hepatoseluler menunjukkan penurunan bermakna setelah vaksinasi hepatitis B. Penelitian kohort di Taiwan menunjukkan penurunan insidens hepatoseluler karsinoma pada anak yang berumur antara 6-9 tahun setelah dilakukan vaksinasi, yaitu dari 0,52 menjadi 0,13 per-100.000. ${ }^{5}$ Vaksinasi hepatitis B merangsang pembentukan hepatitis $B$ surface antibody (anti Hbs), yang seiring dengan waktu mengalami penurunan. ${ }^{6-8}$

Beberapa penelitian menunjukkan bahwa titer anti-Hbs masih memberikan efek proteksi pada 2-4 tahun, bahkan sampai 10 tahun setelah vaksinasi primer. ${ }^{9,10}$ Penelitian yang dilakukan oleh Lin $\mathrm{dkk}^{11}$ memperlihatkan penurunan efek proteksi anti-Hbs pada 951 anak tanpa vaksinasi booster, yaitu $71,1 \%$ pada umur 7 tahun dan 37,4\% pada umur 12 tahun. Pada penelitian yang dilakukan di Alaska, 88\% (182 dari 208) anak yang divaksinasi dengan hepatitis $B$ setelah lahir pada umur 4 tahun tidak ditemukan anti-Hbs. ${ }^{12}$ Sedangkan penelitian yang dilakukan di Nederland, follow up yang dilakukan setelah 15 tahun, 30\% tidak terdeteksi anti-Hbs. ${ }^{13}$ Penelitian yang dilakukan oleh Jafarzadeh dkk, ${ }^{14}$ mendapatkan kadar protektif anti-Hbs pada $47,9 \%$ anak setelah 10 tahun imunisasi hepatitis B. Pada beberapa penelitian didapatkan penurunan titer anti-HBs setelah vaksinasi. ${ }^{15-17}$

Pemberian booster saat ini tidak direkomendasikan, tetapi apabila merujuk pada penelitian yang memperlihatkan penurunan kadar anti-HBs setelah 10-15 tahun imunisasi hepatitis B, maka pemberian booster perlu ditinjau kembali. ${ }^{11,18,19}$

\section{Metode}

Penelitian dilaksanakan di SD di kota Padang, pemeriksaan kadar anti-HBs dilakukan di Laboratorium Patologi Klinik RSUP Dr. M. Djamil. Penelitian dilakukan selama 3 bulan, yaitu mulai bulan Januari 2011 sampai bulan Maret 2011. Desain penelitian cross sectional dengan populasi murid SD berumur 10-12 tahun yang telah diimunisasi hepatitis B sebanyak 3 kali. Kriteria inklusi adalah orang tua dan anak setuju ikut dalam penelitian, mempunyai kartu menuju sehat/ data vaksinasi. Kriteria eksklusi adalah menderita penyakit keganasan, hepatitis, kelainan hematologi yang memerlukan transfusi darah serial. Sampel minimal yang dibutuhkan adalah 96 orang.

Sampel diperoleh melalui cara cluster random sampling. Daftar SD diperoleh dari Dinas Pendidikan Kota Padang. Dari seluruh SD yang terdapat di kota Padang, dipilih 12 sekolah secara random. Semua siswa yang termasuk populasi penelitian di SD terpilih diambil sebagai sampel penelitian.

Sampel yang memenuhi kriteria inklusi diikutsertakan dalam penelitian dan dimintakan persetujuan orang tua. Setiap subyek penelitian dilakukan anamnesis dan mengisi kuesioner yang berisi nama, umur/tanggal lahir, jenis kelamin. Semua subyek penelitian diambil \pm $2 \mathrm{ml}$ darah vena, dilakukan pemeriksaan serologis antiHBs dengan metode Enzyme Linked Immunosorbent Assay (ELISA) dengan kit Vidas di Laboratorium Patologi Klinik RS. Dr. M. Djamil. Sampel darah vena diambil oleh tenaga terlatih dan disimpan dalam tabung vacutainer dengan suhu $2-8^{\circ} \mathrm{C}$. Hasil penelitian disusun dalam bentuk tabel. Dianalisis dengan uji Chi-square, karena variabel independen dan dependennya adalah skala nominal. Batas kemaknaan $\mathrm{p}<0,05$. Data diolah dengan menggunakan program statistik komputer.

\section{Hasil}

Tabel 1 memperlihatkan sebagian besar subyek penelitian adalah perempuan 68 orang $(61,8 \%)$. Seluruh subyek mempunyai status gizi baik (100\%). Sebagian besar subyek mempunyai jadwal imunisasi 0 , 2, dan 4 bulan $(56,4 \%)$.

Tabel 1. Karakteristik subyek penelitian

\begin{tabular}{lll}
\hline Karakteristik & $\mathrm{f}$ & $\%$ \\
\hline Jenis kelamin & & \\
$\quad$ Laki-laki & 42 & 38,2 \\
$\quad$ Perempuan & 68 & 61,8 \\
Status nutrisi & & \\
$\quad$ Gizi baik & 110 & 100 \\
$\quad$ Gizi kurang & 0 & 0 \\
Jadwal imunisasi (bulan) & & \\
$0,1,6$ & 37 & 33,6 \\
$0,2,4$ & 62 & 56,4 \\
$0,2,3$ & 11 & 10 \\
\hline
\end{tabular}




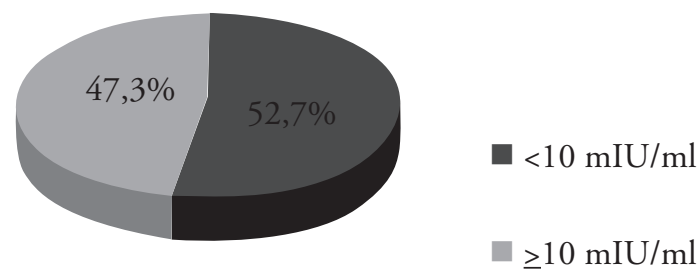

Gambar 1. Distribusi kadar anti-HBs berdasarkan kadar seroproteksi

Gambar 1 memperlihatkan dari 110 sampel didapatkan kadar anti-Hbs $<10 \mathrm{mIU} / \mathrm{ml} 58 \quad(52,7 \%)$ orang dan kadar anti-Hbs $\geq 10 \mathrm{mIU} / \mathrm{ml} 52$ (47,3\%) orang.

Tabel 2 memperlihatkan bahwa semua sampel mempunyai gizi baik. Didapatkan kadar anti-Hbs $<10 \mathrm{mIU} / \mathrm{ml} 58(52,7 \%)$ dan kadar anti-HBs $\geq 10$ $\mathrm{mIU} / \mathrm{ml} 52(47,3 \%)$ orang. Karena semua subyek adalah gizi baik (100\%), sehingga tidak dilakukan uji statistik.

Tabel 3 memperlihatkan kadar anti-Hbs $<10$ $\mathrm{mIU} / \mathrm{ml}$ pada laki-laki $20(47,6 \%)$ dan perempuan $38(55,9 \%)$ orang. Kadar anti-Hbs $\geq 10 \mathrm{mIU} / \mathrm{ml}$ pada laki-laki $22(52,4 \%)$ dan perempuan $30(44,1 \%)$ orang. Uji statistik menunjukkan tidak didapatkan perbedaan bermakna antara kadar anti-Hbs dengan jenis kelamin ( $\mathrm{p}=0,399)$. Kadar anti-Hbs $\geq 10 \mathrm{mIU} / \mathrm{ml}$ terbanyak didapatkan pada umur 10 tahun $23(52 \%)$, sedangkan 12 tahun 7 (35\%) orang. Uji statistik Chisquare menunjukkan tidak didapatkan perbedaan yang bermakna antara kadar anti-Hbs dengan umur. $(\mathrm{p}=0,437)$. Jadwal imunisasi terbanyak dilakukan pada $0,2,3$ bulan $6(54,5 \%)$ orang dengan kadar anti-Hbs $\geq 10 \mathrm{IU} / \mathrm{ml}$. Uji statistik menunjukkan tidak didapatkan perbedaan bermakna antara kadar anti-Hbs dengan jadwal imunisasi $(\mathrm{p}=0,364)$.

Berdasarkan umur subyek, terdapat penurunan kadar anti-HBs yang protektif $(\geq 10 \mathrm{mIU} / \mathrm{ml})$. Semakin meningkat umur, maka semakin menurun kadar anti-HBs yang protektif, baik pada laki-laki maupun perempuan ( Gambar 2).

Tabel 2. Distribusi kadar anti-Hbs berdasarkan status gizi

\begin{tabular}{lcccccc}
\hline \multirow{2}{*}{ Status gizi } & \multicolumn{3}{c}{ Kadar anti-Hbs $(\mathrm{mIU} / \mathrm{ml})$} & \multirow{2}{*}{ Total } & \multirow{2}{*}{$\%$} \\
\cline { 2 - 5 } & $\mathrm{f}$ & $\%$ & $\mathrm{f}$ & $\%$ & & \\
\cline { 2 - 5 } Baik & 58 & 52,7 & 52 & 47,3 & & 110 \\
Buruk & 0 & 0 & 0 & 0 & 0 & 100 \\
\hline
\end{tabular}

Tabel 3. Hubungan kadar anti-Hbs dengan jenis kelamin, umur, dan jadwal imunisasi

\begin{tabular}{|c|c|c|c|c|c|c|c|}
\hline & \multicolumn{4}{|c|}{ Kadar anti-Hbs $(\mathrm{mIU} / \mathrm{ml})$} & \multirow[t]{3}{*}{ Total } & \multirow[t]{3}{*}{$\%$} & \multirow{3}{*}{$\mathrm{p}$} \\
\hline & \multicolumn{2}{|c|}{$<10$} & \multicolumn{2}{|c|}{$\geq 10$} & & & \\
\hline & $f$ & $\%$ & $f$ & $\%$ & & & \\
\hline \multicolumn{8}{|l|}{ Jenis kelamin } \\
\hline Laki-laki & 20 & 47,6 & 22 & 52,4 & 42 & 100 & 0,399 \\
\hline Perempuan & 38 & 55,9 & 30 & 44,1 & 68 & 100 & \\
\hline \multicolumn{8}{|l|}{ Umur (tahun) } \\
\hline 10 & 21 & 48 & 23 & 52 & 44 & 100 & 0,437 \\
\hline 11 & 24 & 52 & 22 & 48 & 46 & 100 & \\
\hline 12 & 13 & 65 & 7 & 35 & 20 & 100 & \\
\hline \multicolumn{8}{|c|}{ Jadwal imunisasi } \\
\hline $0,1,6$ & 23 & 62,2 & 14 & 37,8 & 37 & 100 & 0,364 \\
\hline $0,2,4$ & 30 & 48,4 & 32 & 51,6 & 62 & 100 & \\
\hline $0,2,3$ & 5 & 45,5 & 6 & 54,5 & 11 & 100 & \\
\hline
\end{tabular}


Lydia Aswati dkk: Faktor-faktor yang berhubungan dengan kadar anti-Hbs pada anak setelah 10-12 tahun imunisasi hepatitis B

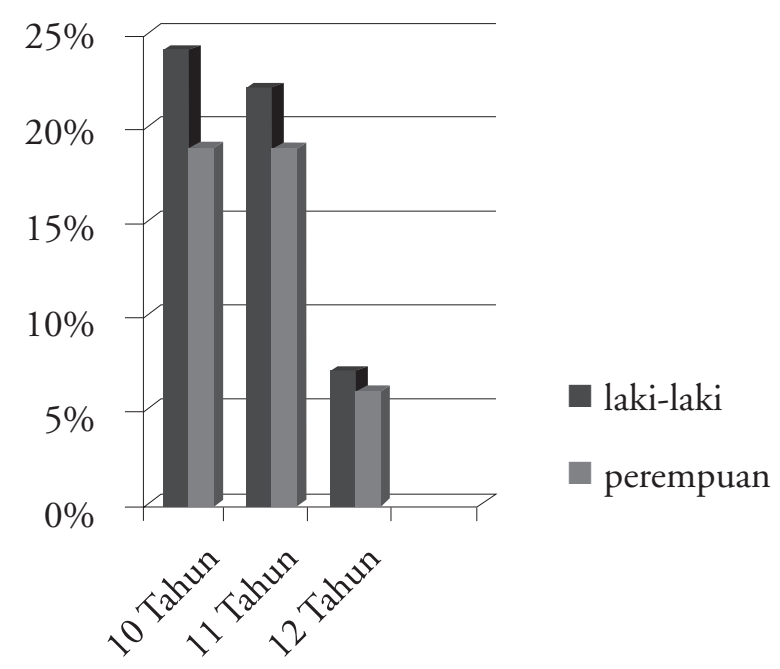

Gambar 2. Gambaran kadar anti-HBs yang protektif setelah 10,11, dan 12 tahun imunisasi hepatitis B

\section{Pembahasan}

Temuan yang kami dapatkan pada anak berumur 10-12 tahun, kadar anti $\mathrm{Hbs}<10 \mathrm{mIU} / \mathrm{ml} \mathrm{52,7 \%}$ dan kadar anti-Hbs $\geq 10 \mathrm{mIU} / \mathrm{ml} \mathrm{47,3 \%}$. Hasil tersebut tidak terlalu berbeda dibandingkan dengan penelitian yang dilakukan oleh Jafarzadeh $\mathrm{dkk}^{14}$ yang mendapatkan kadar anti-Hbs $\geq 10 \mathrm{mIU} / \mathrm{ml}$ setelah 10 11 tahun imunisasi hepatitis B adalah $47,9 \%$, imunisasi dilakukan pada saat umur $0,1,5$, dan 9 bulan. Mariano $\mathrm{dkk}^{20}$ mendapatkan kadar anti-HBs $\geq 10 \mathrm{mIU} / \mathrm{ml} 74 \%$ setelah 10-11 tahun imunisasi hepatitis B. Di Taiwan didapatkan penurunan kadar seroproteksi anti-HBs dari $71,1 \%$ saat berumur 7 tahun menjadi $37,4 \%$ saat berusia 12 tahun. ${ }^{11}$ Penelitian di Alaska setelah 10 tahun imunisasi mendapatkan kadar anti-HBs $10 \mathrm{mIU} / \mathrm{ml}$ pada $76 \%$ anak. ${ }^{17}$ Pada penelitian yang dilakukan di Iran pada anak yang berumur 10-11 tahun, dari 146 anak yang mendapat vaksinasi hepatitis B pada umur 0,1,5, dan 9 bulan, didapatkan anti-HBs protektif $47,9 \%{ }^{21}$

Pada penelitian kami, terdapat $58(52,7 \%)$ orang dengan kadar anti $\mathrm{HBs}<10 \mathrm{mIU} / \mathrm{ml}$, sebagian besar perempuan $38(55,9 \%)$ dan laki-laki 20 $(47,6 \%)$ orang. Sebagian besar berumur 12 tahun serta mempunyai jadwal imunisasi 0,1,6 bulan. Seiring dengan peningkatan umur, maka akan terjadi penurunan kadar anti-HBs. Selain jenis kelamin, jadwal imunisasi, beberapa faktor yang mempengaruhi kadar anti-HBs setelah vaksinasi, seperti status imun, genetik, kualitas dan kuantitas vaksin, penyakit keganasan, dan penyakit kronik.

Pada beberapa penelitian menunjukkan adanya respon anamnestik pada kadar anti-HBs yang rendah maupun yang tidak terdeteksi. Di lain pihak, produksi anti-HBs dari sel B sirkulasi menandakan memori imun. ${ }^{22}$ Setelah injeksi vaksin hepatitis B, titer antiHBs meningkat secara dramatis. ${ }^{23}$ Adanya limfosit $\mathrm{B}$ memori setelah vaksinasi hepatitis B mengindikasikan terdapat sel B sirkulasi yang memproduksi anti-HBs in vitro, bahkan pada keadaan tidak terdeteksi anti-HBs di serum dapat disertai peningkatan yang cepat dari anti-HBs setelah dosis booster. ${ }^{24}$

Penurunan kadar anti-Hbs terjadi seiring dengan peningkatan umur. Pada penelitian kami, dilakukan pada anak berumur 10-12 tahun yang telah mendapat vaksinasi hepatitis B 3 kali pemberian pada saat bayi, menunjukkan kadar anti-Hbs yang rendah $(<10 \mathrm{mIU} / \mathrm{ml}) 52,7 \%$ serta $(\geq 10 \mathrm{mIU} / \mathrm{ml}) \quad 47,3 \%$. Pada penelitian di Taiwan setelah 12 tahun vaksinasi hepatitis B didapatkan kadar anti-HBs $\geq 10 \mathrm{mIU} / \mathrm{ml}$ sebanyak 37,4\%. ${ }^{11}$ Beberapa penelitian menyarankan pemberian vaksinasi hepatitis B yang lebih awal, agar mendapatkan kadar anti-Hbs $\geq 10 \mathrm{mIU} / \mathrm{ml}$ pada interval 79\%-85\% pada umur 10-12 tahun setelah vaksinasi. ${ }^{25}$

Kami tidak mendapatkan perbedaan bermakna kadar anti-HBs antara laki-laki dan perempuan. Penelitian Middleman dkk, ${ }^{26}$ juga tidak mendapatkan perbedaan bermakna antara kadar anti-HBs dengan jenis kelamin. Sedangkan penelitian yang dilakukan di Iran dan Cina, perempuan menunjukkan respon antibodi yang lebih tinggi dibandingkan laki-laki. ${ }^{27,28}$ Pada beberapa penelitian didapatkan penurunan jumlah limfosit $\mathrm{T}$ pada laki-laki dibandingkan perempuan. ${ }^{29}$ Serta laki-laki mempunyai kadar serum IgM dan IgG yang lebih rendah. Respon imun yang berbeda antara laki-laki dan perempuan dipengaruhi pula oleh hormon steroid sex seperti estrogen, progesteron, dan testosteron yang berbeda pada masing-masing jenis kelamin. ${ }^{30}$

Pada uji statistik menunjukkan, kami tidak mendapatkan perbedaan bermakna antara kadar anti$\mathrm{Hbs}$ dengan jadwal imunisasi. Secara persentase, kadar anti-HBs $\geq 10 \mathrm{mIU} / \mathrm{ml}$ terbanyak pada jadwal 0,2 , dan 3 bulan (54,5\%). Berbeda dengan jadwal imunisasi 
yang dianjurkan Ikatan Dokter Anak Indonesia (IDAI) adalah 0,1 ,dan 6 bulan. Variasi jadwal imunisasi cukup efektif untuk merangsang kadar imunitas yang tinggi pada bayi dan anak. ${ }^{31}$ Penelitian oleh Muhammad $\mathrm{dkk},{ }^{32}$ yang merupakan penelitian cross sectional, membandingkan 2 jadwal imunisasi hepatitis B, didapatkan respons imun yang sama setelah vaksinasi pada jadwal imunisasi 0,2,9 bulan ataupun pada 3,4,9 bulan. Penelitian Damme dkk, ${ }^{33}$ yang menilai kadar anti-Hbs setelah 5 tahun imunisasi hepatitis B, membandingkan 2 jadwal imunisasi, yaitu grup A diberikan pada 0,6 bulan sedangkan grup B pada 0,1 , 6 bulan pada kelompok umur 11-15 tahun, didapatkan kadar anti-HBs $\geq 10 \mathrm{mIU} / \mathrm{ml}$ pada grup A 79,5\%, sedangkan pada grup B 91,4\%.

Kami mendapatkan seluruh subyek penelitian mempunyai status gizi baik (100\%), karena menentukan status gizi menurut bawah garis merah (BGM) atau tidak BGM dalam KMS, sedangkan gizi baik menurut KMS adalah $\geq-2$ sampai $\leq 2$ SD Z score, tidak dibedakan subyek dengan gizi kurang atau gizi lebih, sedangkan menurut $\mathrm{Z}$ score berdasarkan indikator $\mathrm{BB} / \mathrm{U}$ dinyatakan gizi baik apabila $\mathrm{Z}$ score antara $\geq-2$ sampai $\leq 2$, gizi kurang jika $Z$ score $\geq-3 S D$ sampai dengan $<-2$, gizi lebih apabila $>+2$, serta gizi buruk jika $Z$ score $<-3 .{ }^{34}$ Pada penelitian kami semua subyek adalah gizi baik (100\%), sehingga uji statistik tidak dapat dilakukan untuk melihat hubungan antara status gizi dengan kadar anti-HBs setelah 1012 tahun imunisasi hepatitis B. Berdasarkan kadar anti-HBs yang protektif $(\geq 10 \mathrm{mIU} / \mathrm{ml})$ pada subyek dengan gizi baik $47,3 \%$, sedangkan $(<10 \mathrm{mIU} / \mathrm{ml})$ $52,7 \%$, yang berkemungkinan subyek berada pada $\mathrm{Z}$ score antara $\geq-3$ sampai -2 (gizi kurang). Penelitian yang dilakukan di Tanzania pada anak yang berumur $<5$ tahun, didapatkan gizi baik $70,3 \%$, tetapi tidak terdapat hubungan yang bermakna antara status gizi dengan kadar anti-HBs. ${ }^{35}$ Penelitian yang dilakukan untuk melihat hubungan antara malnutrisi dan respons vaksin hepatitis B pada bayi Egypt, sebagai subyek 27 bayi dengan marasmik kwashiorkor dan kelompok kontrol 13 orang subyek yang sehat. Kadar anti-Hbs bermakna lebih tinggi pada kelompok kontrol. ${ }^{36}$

\section{Kesimpulan}

Terdapat penurunan kadar anti-HBs protektif pada anak yang berumur lebih besar. Tidak terdapat hubungan yang bermakna antara jenis kelamin dan jadwal imunisasi dengan kadar anti_HBs setelah 1012 tahun imunisasi Hepatitis B. Disarankan untuk dipertimbangkan pemberian booster setelah 10-12 tahun imunisasi hepatitis $\mathrm{B}$ dan dibutuhkan penelitian lebih lanjut untuk menentukan lama memori imunologi setelah vaksinasi hepatitis B.

\section{Daftar pustaka}

1. Julitasari, U A. Permasalahan penyakit hepatitis virus di Indonesia. Dalam: Z Z, J B, P P, H O, eds. Tinjauan komprehensif hepatitis virus pada anak. Jakarta: Balai Penerbit FKUI; 2000.h.1-31.

2. Chongsrisawat V, Yoocharoen P, Theamboonlers A, Tharmaphornpilas P, Warinsathien P, Sinlaparatsamee S. Hepatitis B seroprevalence in Thailand: 12 years after hepatitis B vaccine integration into the national expanded programme on immunization. Jr Trop Med Inter Health 2006;11:1496-502.

3. Lavanchy D. Hepatitis B virus epidemiology, disease burden, treatment and current and emerging prevention and control measures. J Viral Hepat 2004;11:97-107.

4. Lee W. Hepatitis virus infection. N Engl J Med 1997;337:1733-44.

5. Chang M, Chen C, Lai M, Hsu H, Wu T, Kong M. Universal hepatitis $\mathrm{B}$ vaccination in Taiwan and the incidence of hepatocellular carcinoma in children Taiwan Childhood Hepatoma Study Group. N Engl J Med 1997; 336:1855-9.

6. Chen H, Chang C, Wong M, Huang F, HC L, Lin Cd. Pediatric fulminant hepatic failure in endemic areas of hepatitis B infection: 15 years after universal hepatitis B vaccination. Hepatology 2004;39:58-63.

7. Armstrong G, Mast E, Wojczynski M, Margolis H. Childhood hepatitis B virus infections in the United States before hepatitis B immunization. Pediatrics 2001;108:1123-8.

8. Hidayat B, Pujianto P. Hepatitis B. In: Ranuh I, Suyitno H, Hadinegoro S, Kartasasmita C, Ismoedijanto, Soedjatmiko, penyunting. Pedoman imunisasi Indonesia. Jakarta: Ikatan Dokter Anak Indonesia; 2008.h.135-42.

9. Chang M, Shau W, CJ C, et al. Hepatitis B vaccination and hepatocellular carcinoma rates in boys and girls. JAMA 2000;284:3040-42.

10. Chongsrisawat V, Theamboonlers A, Khwanjaipanich S, Owatanapanich S, Sinlaparatsamee S, Poovorawan Y. Humoral immune response following hepatitis $\mathrm{B}$ 
Lydia Aswati dkk: Faktor-faktor yang berhubungan dengan kadar anti-Hbs pada anak setelah 10-12 tahun imunisasi hepatitis B

vaccine booster dose in children with and without prior immunization. Southeast Asian J Trop Med Public Health 2000;31:623-6

11. Lin Y, Chang M, Ni Y, Hsu H, Chen D. Long term immungenicity and efficacy of universal hepatitis B virus vaccination in Taiwan. J Infect Dis 2003;187:134-8.

12. Petersen K, Bulkow L, McMahon B, Zanis C, Getty M, Peters H, dkk. Duration of hepatitis B immunity in low risk children receiving hepatitis $\mathrm{B}$ vaccinations from birth. J Pediatr Infect Dis 2004;23:650-6.

13. Banatvala J, Van Damme P. Hepatitis B vaccine: Do we need boosters? . J Viral Hepat 2003;10:1-6.

14. Jafarzadeh A, SJ M. Persistence of anti-HBs antibody and immunological memory in children vaccinated with hepatitis B vaccine at birth. J Ayub Med 2006;18:1-9.

15. Plotkin S, Orenstein W. Hepatitis B vaccine. Dalam: Mahoney F, Kane M, penyunting. Vaccines. Edisi ketiga. Philadelphia; 1999.h.158-79.

16. Goh K, Oon C, Heng B, Lim B. Long term immunogenicity and efficacy of a reduced dose of plasma-derived hepatitis $\mathrm{B}$ vaccine in young adults. Bull W H O 1995;73:523-7.

17. Wainwright R, Buklow R, Parkinson A, Zanis C, McMahon B. Protection provided by hepatitis $\mathrm{B}$ vaccine in a Yupik Eskimo population-results of a 10-year study. J Infect Dis 1997;175:674-7.

18. McMahon B, Bruden D, Petersen K, et al. Antibody level and protection after hepatitis $\mathrm{B}$ vaccination : results of a 15-year follow-up. Ann Intern Med 2005;142:333-41.

19. Whittle H, Jaffar S, Wansbrough M, Mendy M, Dumpis Ud. Observational study o vac-cine efficacy 14 years after trial of hepatitis B vaccination in Gambian children. $\mathrm{Br}$ Med J 2002;325:569-74.

20. Mariano A, dkk. Long-term immunogenicity and efficacy assessment of anti-hepatitis B virus $\mathrm{HBV}$ ) vaccination in Italian children. Hepatology 2004;1:178.

21. Jafarzadeh A, Montazerifar S. Persistence of anti-HBs antibody and immunological memory in children vaccinated with hepatitis B vaccine at birth. J Ayub Med Coll Abbottabad 2006;18:4-9.

22. Manatvala J, Van Damme P. Hepatitis B vaccine- do we need boosters?. J Viral Hepatology 2003;1: 1-6.

23. Lu C, Chiang B, Chen P, dkk. Humoral and cellular immune responses to a hepatitis $\mathrm{B}$ vaccine booster 15-18 years after cellular immunization. J Infect Dis 2008;10:1419-26.

24. West D, Calandra G. Vaccine induced immunological memory for hepatitis B surface antigen: implication for policy on booster vaccination. Vaccine 1996;14:101926.

25. Yuen M. Twelve-year follow-up of a prospective randomized trial of hepatitis $\mathrm{B}$ recombinant DNA yeast vaccine versusplasma-derived vaccine without booster doses in children. Hepatology 2003;29:924-7.

26. Middleman A, Kozinets C, Robertson L, Durant R, Emans S. The effect of late doses on the achievement of seroprotection and antibody titer levels with hepatitis B immunization among adoslescents. Pediatics 2001;107:1065-9.

27. Chen C, Yen C, Wu Wd. Epidemiology of hepatitis $B$ virus infection among young adults in Taiwan, China after public vaccination program. Chin Med J 2007;120:1155-8.

28. Shamsizadeh A, Makvandi M, Shoshtari G. Prevalence of anti hepatitis B surface antibody among children in Ahvaz, Iran, five years after vaccination JJM 2011; 4:49-54.

29. Giltay E, Fonk J, Blomberg B, Drexhage H, Schalkwijk C, LJ G. In vivo effects of sex steroids on lymphocyte responsiveness and immunoglobulin levels in humans. J Clin Endocrinol Metab 2000;85:1648-57.

30. Bouman A, Heineman M, Faas M. Sex hormones and the immune response in human. Human Reproduction Update 2005;11: 411-23.

31. Halsey N, Moulton L, Donovan Cd. Hepatitis B vaccine administered to children and adolescents at yearly intervals. Pediatrics 1999;103:1243-47.

32. Muhammad E, Carmelia R, Yuliati, Lubis I, Manoeroeng S. Characteristic of immune response of hepatitis B immunization on infant with two different schedules. Paediatr Indones 2001;41:197-201.

33. Damme P, Moiseeva A, Marichev Id. Five years follow-up following two or three doses of a hepatitis B vaccine in adolescents aged 11-15 years: a randomised controlled study BMC Infect Dis 2010;10:1-8.

34. Dibley $M$, Staeling N, Nieburg P. Interpretation of $\mathrm{Z}$-score antropometric indicators derived from the international growth reference. Am J Clin Nutr 1987;46:749-62.

35. Metodi J, Aboud S, Mpembeni R, Munubhi E. Immunity to hepatitis $\mathrm{B}$ vaccine in Tanzanian under-5 children. Annals of Tropic Paediatr 2010;30:129-36.

36. El-Gamal Y, Aly R, Hossny E, Afify E, D e-T. Response of Egyptian infants with protein calorie malnutrition to hepatitis B vaccination. J Trop Pediatr 1996;42:144-5. 